Endocrinol. Japon. 1990, 37 (2), 293-297

\title{
NOTE
}

\section{Glucagon-Like Peptide-1(7-37) does not Stimulate either Hepatic Glycogenolysis or Ketogenesis}

\author{
Yasuko MURAYAMA, Koichi KAWAI, Seiji SUZUKI, Shinichi OHASHI* \\ AND KameJIRo YAMASHITA
}

Institute of Clinical Medicine, University of Tsukuba,

* The Research Institute for Polymer and Textiles,

Tsukuba, Ibaraki, Japan

\begin{abstract}
Recent Studies have demonstrated that glucagon-like peptide-1 (GLP)(7-37) has more potent insulinotropic activity than glucagon. We therefore examined the effect of GLP-1(7-37) on liver metabolism using rat liver perfusion system. Ten nM GLP-1(7-37) did not affect glucose, ketone body and cAMP outputs from the perfused liver. Whereas, the same dose of glucagon stimulated these outputs significantly. When $10 \mathrm{nM}$ GLP-1(7-37) perfused $5 \mathrm{~min}$ before the administration of $10 \mathrm{nM}$ glucagon, the above stimulatory effects of glucagon were not affected. These results indicate that truncated GLP-1 has no effect on hepatic glycogenolysis and ketogenesis dissociating from its potent insulinotropic activity.
\end{abstract}

Mammalian preproglucagon contains two glucagon-like peptides (GLPs), GLP-1 and GLP-II (Bell et al., 1983; Lopez et al., 1983; Heinrich et al., 1984). The posttranslational processing of preproglucagon differs in pancreas and intestine (prskov et al., 1986; Mojsov et al., 1986). A naturally occurring GLP-1 from small intestine is considered to be proglucagon(78-107 or 108) and thus represents a truncated form of GLP-1, GLP-1 (7-36) amide or GLP-1 (7-37). The amino-acid sequence of truncated GLP-1 has a high

Received September 19, 1989

Address correspondence to YASUKO MURAYAMA, M. D., Institute of Clinical Medicine, University of Tsukuba, Tsukuba, Ibaraki-ken 305, Japan degree of homology with glucagon, which suggests that truncated GLP-1 possesses a similar biological activity to glucagon.

Recent studies have demonstrated that truncated GLP-1 possesses more potent insulinotropic activivity than glucagon or GLP-1(1-37) (Mojsov et al., 1987 ; prskov et al., 1988 ; Kawai et al., 1989). However, it has not been reported whether truncated GLP-1 activates hepatic glycogenolysis and ketogenesis or not, although GLP-1 (1-37), having a weak insulinotropic activity (Mojsov et al., 1987 ; Kawai et al., 1989), did not stimulate the glycogenolysis in rat hepatocytes (Shimizu et al., 1986).

We therefore examined the effects of truncated GLP-1, GLP-1 (7-37), on liver metabolism using a liver perfusion system. 


\section{Materials and Methods}

\section{Materials}

GLP-1 (1-37) and (7-37) were synthesized by the stepwise solid-phase method using an automatic synthesizer (Beckman 990-B, Beckman Instruments, Fullerton, USA), and then purified by HPLC as previously described (Kawai et al., 1989). Glucagon was purchased from Sigma (St. Louis, USA).

\section{Rat liver perfusion}

Under pentobarbital anesthesia, the liver was isolated from fed normal male Wistar rats ( 9 weeks old) and perfused in situ by the method of Sugano et al. (1978). The perfusate was a Krebs-Ringer-Tris buffer $(20 \mathrm{mM}$ Tris- $\mathrm{HCl}$, pH 7.4 , oxygenated with $\left.100 \% \quad \mathrm{O}_{2}\right)$, containing $0.1 \%$ soybean oil emulsion (Intrafat ${ }^{\circledR}$; Daigo Eiyo, Osaka, Japan) and it was infused from the portal vein at a constant speed of $20 \mathrm{ml} / \mathrm{min}$ without recirculation (Okuda et al., 1987). After a $30 \mathrm{~min}$ initial equilibration period, $3 \mathrm{ml}$ of perfusate was collected every 1 or $2 \mathrm{~min}$ from a canula inserted into the superior vena cava. The infusion of GLP-1 (1-37), (7-37) and glucagon was performed by changing to the perfusatereservoir containing the above perfusate and these peptides.

\section{Analytical methods}

The glucose concentration of the effluent perfusate was determined by the glucose oxidase method using a Glucose Analyzer-2 (Beckman, Fullerton, USA). The cyclic AMP level was determined with a commercial RIA kit (Yamasa RIA Kit ${ }^{\circledR}$, Choshi, Japan). The total ketone body (acetoacetate plus 3-hydroxybutyrate) concentration was measured by the enzymatic method (Ketone test ${ }^{\circledR}$, Sanwa, Nagoya, Japan).

\section{Statistical methods}

All data in this paper are expressed as the mean \pm SE. Data are analyzed by means of the Wilcoxon paired sample test. $\mathrm{P}<0.05$ was considered significant.
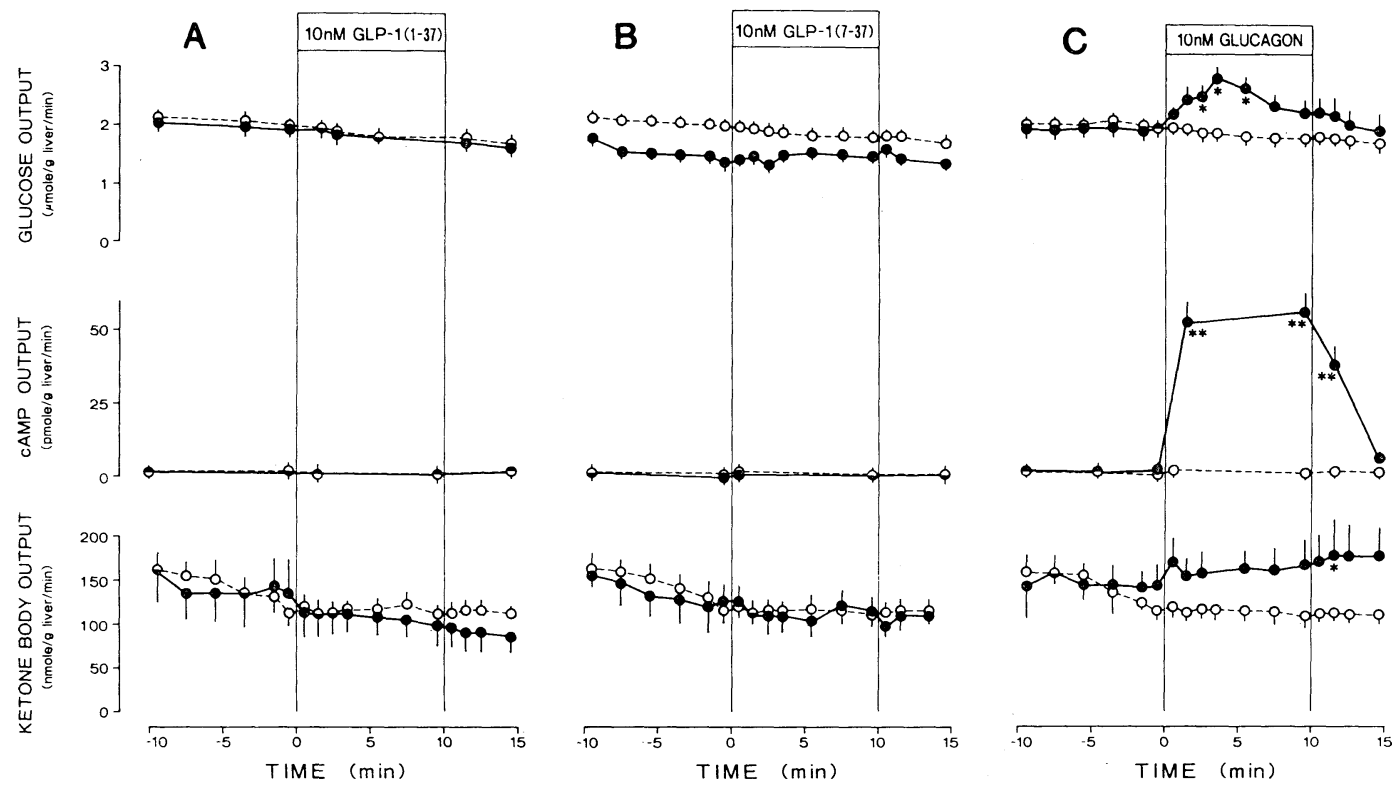

Fig. 1. Effects of GLP-1 (1-37) (A), GLP-1 (7-37) (B) and glucagon (C) on glucose, total ketone body (acetoacetate plus 3-hydroxybutyrate) cAMP outputs from the perfused rat liver $(\mathrm{n}=6$, mean \pm SE). - - - with $10 \mathrm{nM}$ GLP-1(1-37), GLP-1 (7-37), and glucagon. - $\bigcirc-$ without these peptides. Values significantly different from the preceding baseline (mean value during initial $10 \mathrm{~min})$ are shown by asterisks $(* ; \mathrm{P}<0.05$, **; $\mathrm{P}<0.01)$. 


\section{Results}

Effects of GLP-1 (1-37), (7-37) and glucagon on glucose, ketone body and cAMP output from the perfused rat liver.

The glucose and ketone body outputs gradually decreased during the $25 \mathrm{~min}$ experimental period without the infusion of peptides, but the decrease was not significant, showing as open circles in Fig. 1. The infusion of $10 \mathrm{nM}$ GLP-1 (1-37) or (7-37) for $10 \mathrm{~min}$ did not change glucose and ketone body outputs (Fig. 1-A and B), but 10 $\mathrm{nM}$ glucagon significantly stimulated these outputs (Fig. 1-C). Cyclic AMP output was negligible during the basal perfusion $(2.0 \pm 0.8 \mathrm{pmole} / \mathrm{g}$ liver $/ \mathrm{min})$ and did not change during the infusion of GLP-1 (137) and (7-37) (Fig. 1-A and -B). The infusion of glucagon clearly stimulated cAMP output (from its basal level of $1.8 \pm$ $0.6 \mathrm{pmole} / \mathrm{g}$ liver $/ \mathrm{min}$ to $56.8 \pm 26.9 \mathrm{pmole} / \mathrm{g}$ liver/min $10 \mathrm{~min}$ after the administration of glucagon; $\mathrm{P}<0.01)$.

Effects of pre-perfusion of GLP-1 (7$37)$ on the stimulation of glucose, ketone body and cAMP outputs by glucagon

As shown in Fig. 2, the degree of stimulation of glucose, ketone body and cAMP outputs by $10 \mathrm{nM}$ glucagon did not change

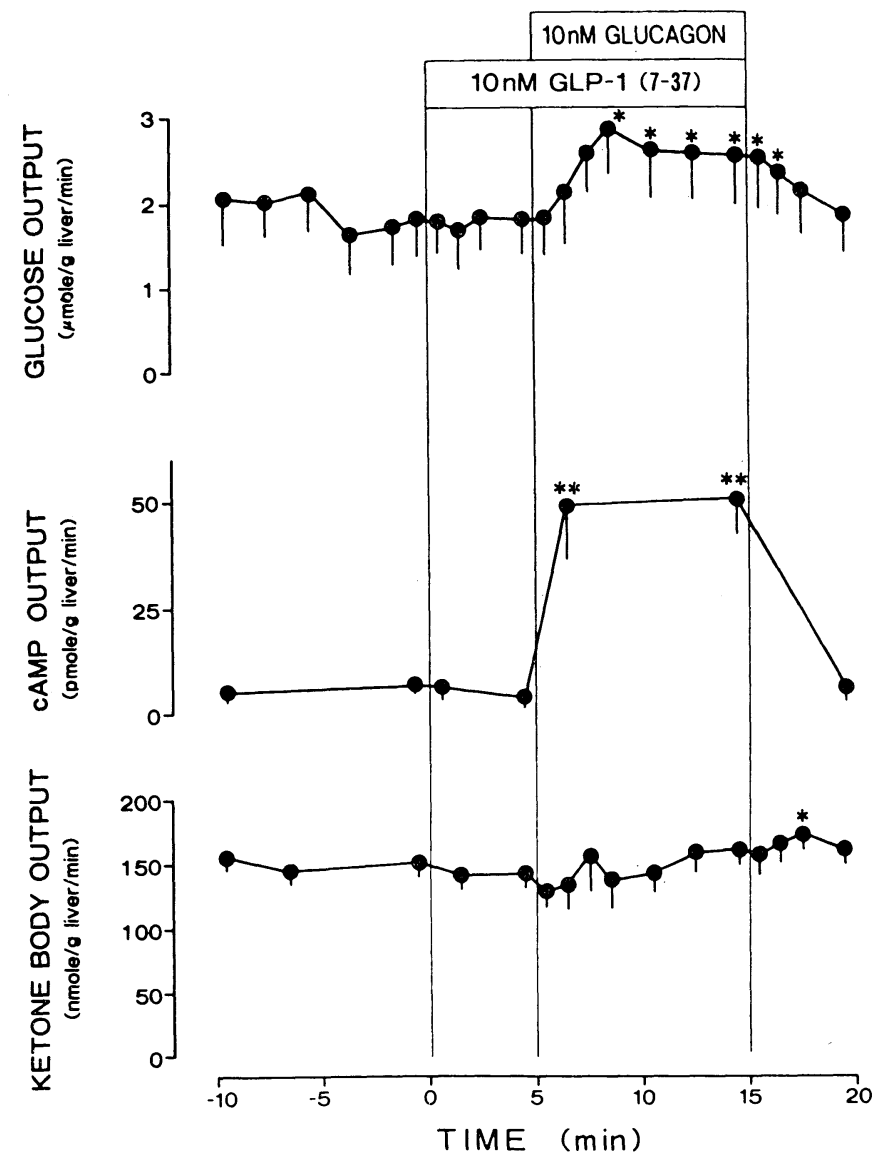

Fig. 2. Effects of pre-perfusion of GLP-1 (7-37) on the stimulation of glucose, ketone body and cAMP output from perfused rat livers by glucagon $(n=5, \quad$ mean $\pm S E)$. The infusion of $10 \mathrm{nM}$ GLP1(7-37) was started $5 \mathrm{~min}$ before the infusion of $10 \mathrm{nM}$ glucagon and continued during $10 \mathrm{~min}$ of infusion of glucagon. Values significantly different from the preceding baseline (mean values during initial $10 \mathrm{~min}$ ) are shown by asterisks (*; $\mathrm{P}<$ 0.05). 
significantly during the co-infusion of $10 \mathrm{nM}$ GLP-1 (7-37) (Fig. 1-C vs. Fig. 2).

\section{Discussion}

In this study, we examined the effect of GLP-1 (7-37) on glucose and ketone body outputs from the perfused rat liver since it has higher insulinotropic activity than glucagon. The GLP-1 (7-37) used in this experiment has 100-1000 times more potent insulinotropic activity than GLP-1 (1-37) and slightly higher inslinotropic activity than glucagon (Kawai et al., 1989). A recent study demonstrated that $10^{-11} \mathrm{M}$ GLP-1 (7-37) significantly stimulates insulin release (Weir et al., 1989). However, 10 $\mathrm{nM}$ of it did not stimulate glucose, ketone body and cAMP outputs from the perfused rat liver, as GLP-1 (1-37) did not, and the same dose of glucagon stimulated them. Furthermore, GLP-1 (7-37) did not change the degree of stimulation of glucose, ketone body and cAMP outputs by glucagon, which indicate that the affinity of GLP-1 (7-37) for glucagon receptor in rat liver is extremely low. Therefore, the present results indicate that GLP-1 (7-37) does not stimulate hepatic glycogenolysis and ketogenesis even at a supra-physiological concentration (Kreymann et al., 1987), and that the biological activity of GLP-1 (7-37) on pancreatic islet cells is extremely different from that on hepatocytes.

Previous studies demonstrate that GLP-1 (1-37) or GLP-1 (1-36) amide does not affect hepatic glucose output in higher animals (Ghiglione et al., 1984), and that it has no specific high affinity receptor on liver plasma membrane or does not crossreact with glucagon receptors on it (Hoosein and Gurd 1984; Ghiglione et al., 1985; Shimizu et al., 1986), whereas a specific receptor for GLP-1 was identified in rat brain and lung (Hoosein and Guard 1984; Kanse et al., 1988). Our results concerning
GLP-1 (1-37) are consistent with the results of these previous studies.

On the other hand, $3.5 \mathrm{nM}$ of piscine GLP and human GLP-1 (1-37) stimulated gluconeogenesis in isolated trout and salmon hepatocytes, although it did not stimulate the production of either cAMP or cGMP (Mommsen et al., 1987). These results suggest that there are big differences between GLP-1 receptor and its signal transduction in animals and fish, because the bolus injection of GLP-1 (1-36) amide into rabbits did not affect the plasma glucose and insulin levels at $20 \mathrm{~min}$ after the injection (Ghiglione et al., 1984).

In summary, the present study indicates that 1) GLP-1 (7-37) does not stimulate either glycogenolysis or ketogenesis in rat liver as GLP-1 (1-37) does not, and 2) GLP-1 (7-37) does not modulate the glucagon's actions on rat liver, which leads us to speculate that there is no receptor for truncated GLP-1 on rat liver plasma membrane, and/or that the affinity of it for glucagon receptor on rat hepatocyte is extremely low.

\section{References}

Bell, G. I., R. F. Santerre and G. T. Mullenbach (1983). Hamster preproglucagon contains the sequence of glucagon and two related peptides. Nature (Lond) 302, 716-718.

Ghiglione, M., L. O. Uttentha1, S. K. George and S. R. Bloom (1984). How glucagon-like is glucagon-like peptide-1? Diabetologia 27, 599-600.

Ghiglione, M., E. Blazquez, L. O. Uttenthal, J. G. de Diego, E. Alvarez, S. K. George and S. R. Bloom (1985). Glucagon-like peptide1 does not have a role in hepatic carbohydrate metabolism. Diabetologia 28, 920-921.

Heinrich, G., P. Gros and J. F. Habener (1984). Glucagon gene sequence: four of six exons encode separate functional domains of rat preproglucagon. J. Biol. Chem. 259, 1408214087.

Hoosein, N. M. and R. S. Gurd (1984). Human 
glucagon-like peptides 1 and 2 activate rat brain adenylate cyclase. FEBS Lett. 178, 8386.

Kanse, S. M., B. Kreymann, M. A. Ghatei and S. R. Bloom (1988). Identification and characterization of glucagon-like peptide-1 (7-36) amide-binding sites in the rat brain and lung. FEBS Lett. 241, 209-212.

Kawai, K., S. Suzuki, S. Ohashi, H. Mukai H. Ohmori, Y. Murayama and K. Yamashita (1989). Comparison of the effects of glucagonlike peptide-1-(1-37) and-(7-37) and glucagon on islet hormone release from isolated perfused canine and rat pancreases. Endocrinology 124, 1768-1773.

Kreymann, B., G. Williams, M. A. Ghatei and S. R. Bloom (1987). Glucagon-like peptide-1 7-36: a physiologic incretin in man. Lancet 2, 1300-1303, 1987.

Lopez, L. C., M. L. Frazier, C. J. Su, A. Humar and G. F. Sanders (1983). Mammalian pancreatic preproglucagon contains three glucagon related peptides. Pro. Natl. Acad. Sci. USA 80, 5484-5489.

Mojsov, S., G. Heinrich, I. B. Wilson, H. Ravazzola, L. Orci and J. F. Habener (1986). Preproglucagon gene expression in pancreas and intestine diversifies at the level of posttranslational processing. J. Biol. Chem. 216, 11880-11889.

Mojsov, S., G. C. Weir and J. F. Habener (1987). Insulinotropin: Glucagon-like peptide 1 (7-37) co-encoded in the glucagon gene is a potent stimulator of insulin release in the perfused rat pancreas. J. Clin. Invest. 79,
616-619.

Mommsen, T. P., P. C. Andrews and E. M. Plisetskaya (1987). Glucagon-like peptides activate hepatic gluconeogenesis. FEBS Lett. 219, 227-232.

Okuda, Y., K. Kawai and K. Yamashita (1987). Age-related change in ketone body metabolism : diminished glucagon effect on ketogenesis in adult rats. Endocrinology 120, 2152-2157.

Shimizu, I., M. Hirota, C. Ohboshi and K. Shima (1986). Effect of glucagon-like peptide-1 and -2 on glycogenolysis in cultured rat hepatocytes. Biomed. Res. 7, 431-436.

Sugano, T., K. Suda, M. Shimada and N. Oshino (1978). Biochemical and ultrastructural evaluation of isolated rat liver systems perfused with a hemoglobin-free medium. $J$. Biochem. 83, 995-1007.

Weir, G. C., S. Mojsov, G. K. Hendrick and J. F. Habener (1989). Glucagonlike peptide 1 (7-37) actions on endocrine pancreas. Diabetes $38,338-342$.

prskov, C., J. J. Holst, S. Knuhtsen, F. G. A. Baldissed, S. S. Poulsen and O. V. Nielsen (1986). Glucagon-like peptides GLP-1 and GLP-2, predicted products of the glucagon gene, are secreted separately from pig small intestine but not pancreas. Endocrinology 119, 1467-1475.

prskov, C., J. J. Holst and O. V. Nielsen (1988). Effect of truncated glucagon-like peptide-1 [proglucagon-(78-107) amide] on endocrine secretion from pig pancreas, antrum nonantral stomach. Endocrinology 123, 20092013. 